\title{
DAYAK AND MALAY BROTHERHOOD IN THE MALAY COLLECTIVE MEMORY OF POST- INDEPENDENCE INDONESIA ${ }^{1}$
}

\author{
Hermansyah \\ IAIN Pontianak \\ Email: hermansyahii@yahoo.com
}

\begin{abstract}
Each community in the world has a past in which their existence is commonly determined by things happening in their past. To preserve their past a community needs means of transmission, among others, through oral traditions such as stories, mantra, and way of life. They inherit stories, mantra, and ways of life with values that have related meanings to their life. The heritage of these things is very important to preserve and develop the collective identity of the community. As they continue to be passed down, they become the collective memory of a community. The West Kalimantan Malay society has collective memories that are relatively inherited in the form of oral traditions and other life practices such as cultivation. Part of the collective memory has awakened them to the brotherhood with the people called Dayak today. Nevertheless, the collective memory is confronted with challenges both coming from within themselves and from the outside that may eliminate them without a better replacement.
\end{abstract}

Keywords: Collective, Memory, Dayak, Malay, Local Tradition, Belief, Heritage, Social Relations

\section{INTRODUCTION}

Before Europeans came to West Kalimantan, the terms Dayak and Malay had not been used to identify local people. Popular local identification was the traditional tribal names which can be associated to the place of origin such as the name of the village or the name of the river and language. Within certain limits, this identification is still used today as a marker of the origin of a person. The Dutch came and provided a new identity construction for the

${ }^{1}$ The article is absed on a peper presented at the Dialog Borneo-Kalimantan XIII held on 27-28 Desember 2018. The first basic draft of it is posted at http://teraju.id/berita/persaudaraan-dayak-melayu-dalam-memori-kolektif-orang-melayu-4454/. The terminologi of Pasca Independence era is given to explain the situation of ethnic relation in West Kaliman$\tan$ Barat which is not being discussed within available otoritative resources such as works of Western scholars and the colonial reports that mosltly give more attention to the ecsotism of the people in the region such as head-hunting tradition and other local culture aspects. 
local population of Kalimantan with two main categories namely: Dayak and Malay. Meanwhile the main marker of the construct of ethnic identity was religion. Local people who observed traditional beliefs were called Dayaks. While those who had converted to Islam had a new ethnic identity as Malays. Later, Dayak not only became the identity of local people who embraced the original belief but it was also used to identify those who followed the Christian missionary religion. The most popular terms for the transition of identity to local people who converted to Islam are "to become Malay' or 'to enter Malaydom' or 'to return [and become] Malay' (Veth, 1854; King, 1993; Chalmers, 2007; Heidhues, 2008, Hermansyah, 2010; 2018). The name Dayak itself is actually a 'umbrella name' for hundreds of sub ethnic groups with relatively different languages and cultures.

The issue of Islamic conversion as an entry into Malaydom for local communities in West Kalimantan has emerged at least 160 years ago. For example Veth (1854: 54) reported on the inhabitants of Embau. ${ }^{2}$ According to him, a person's religion means holding a Malay name. Veth (1854: 54) firmly noted: "Daar zij voor eenige jaren den islam hebben aangenomen thans tot de malaijers kunnen gerekend worden." (meaning,"there, a few years before this, they (the inhabitants of the Embau River) have embraced Islam, they may be counted as Malay.") ${ }^{3}$

The Malay-Dayak identification process to local communities based on the beliefs adopted by Dutch colonialists among others is intended for administrative purposes other than of course divide et empera politics. From a colonial point of view, the Dayaks were considered primitive ${ }^{4}$ with their exotic image. While the Malay were considered more cultured because they were religious, became rulers of several kingdoms, and some of them were immigrants. This image slowly but surely affected the local people. The people who were given a new identity as Malays were flattered. Those who were called Malay felt that they had a better social status. Therefore the identification process that distinguishes Malay and Dayak was getting stronger. The further consequence of the kinship between the two --which is actually very strong because of the blood relationship-was increasingly tenuous. In fact, since then there has been negative image of the 'brothers' called Dayak.

2 A name of a river in Kabupaten Kapuas Hulu. The region consits of three lover levels of administrative regions including Kecamatan Jongkong, Kecamatan Hulu Gurung, and Kecamatan Pengkadan.

3 Such identification process is also found within local people who converted to Islam in the past in West Kalimantan (see Enthoven, 2013).

4 A colonial terminology commonly used by Europeans to lebel the people in their collomies which is associated to primitive, pagan and living in small groups of clan contrasted to modern Europeans 
The separation grew stronger when in later times most of the so-called Dayaks then chose Christianity as their formal religion. In contrast, some Dayaks who converted to Islam were still considered Malay. In this context the colonial concept continues to be used. Later researchers are still reporting the same thing as Sellato (1992) who wrote: "Gradually over time religious conversion would result in a reclassification of the Dayak converts as Malay; the local Malay term for this process is masok Melayu ('to become Malay' or 'to enter Malaydom') or sometimes turun Melayu ('to come down [and become] Malay"' 5

The Malay and the Dayak are the two largest ethnic groups in West Kalimantan. Before becoming part of the Republic of Indonesia, these community groups were under the control of local leaders. The relationship between these two ethnic groups has been very dynamic. In some cases the two constructs of colonial identity are faced so as to cause tension. This condition is exacerbated by a handful of people making the Malay-Dayak identity a political tool. The use of ethnic identity as a means of winning the sympathy of the masses is increasingly widespread after the reform era especially in the elections of regional heads of government. The Dayaks began to have the awareness that Kalimantan is a Dayak land and they are the most entitled to inherit and lead on this island. While among the Malays also they developed the same thing that they are natives as well. This situation affects the bureaucracy, when one of these two groups is in power, it will be considered ${ }^{6}$ there is dominance in government and in related sectors.

Meanwhile, several violent conflicts with ethnic backgrounds have occurred here. Although some of these conflicts do not involve Dayaks and Malays directly, it has caused deep historical wound to the people of West Kalimantan. However, it is not impossible that a conflict involving ethnic Dayaks and Malays will occur if both ethnic groups continue to be exposed to the pragmatic political interests of a particular person or group of people. The potential for conflict vulnerability in West Kalimantan has been hypothesized by Prof. Syarief I. Alqadrie (2007) which in its history happened every 30 years. One example of tension involving ethnic Dayak and Malay-Muslim members who almost instigated an open conflict, for example, occurred when the first parade

${ }^{5}$ Lately the condition has not been found animor in the region of Landak. The Kanayatn Dayak who convert to Islam in the region keep their ethnic identity (see Hermansyah (2013). For further reference, see also Prasojo (2011) who discusses the similar pgenomena for Katab Kebahan Dayak in Melawi of West Kalimantan.

6 The word is used for inavilability of research finding with regards to whether the statement is true. In fact, people massively keep the notion within non-formal conversation in their daily life. There is also an understanding about unjust meaning within the term. 
of Gawai Dayak on May 20, 2017. ${ }^{7}$ Previously, there were incidents at Gang Tanjung Harapan and Gang Landak Pontianak in November and December 1999 which also almost spread into conflict between the two ethnic groups. ${ }^{8}$

Amid fears of a conflict that may involve two of the largest groups of people in West Kalimantan, there is a real sense of brotherly feelings toward the Dayaks among the Malays that have been recorded in their common memories. Very likely that consciousness is also present among the Dayaks. This kind of awareness has, among other things, succeeded in maintaining a relatively good relationship for so long between the two largest ethnic groups in West Kalimantan. This is a 'capital' for the people of West Kalimantan to maintain social harmony.

There are various things that still remind local Malay of their Dayak origins into their collective memory, among others: aspects of trust, heritage, social relations, and cultural similarities. This collective memory has been passed down by generations. Unfortunately, behind this collective memory begins to be erased slowly either intentionally or not. This article will describe the collective memory of the Malays that may serve the bond of the two large communities in West Kalimantan. In addition, this paper will also present challenges or even threats to the existence of the collective memory.

\section{COLLECTIVE MEMORY}

There are various terms used to refer to "collective memory". Some scholars prefer the term "cultural memory" (Erll, 2008), whereas most social historians and scientists use the term "social memory" (Olick, 1998; Fentress and Wickham, 1992) and "collective memory" (Lipsitz, 1990). In practice, this terminology differs due to different approaches to study it.

Memory is an individual phenomenon that begins with the activity of remembering in a person's head. Every meaning and symbol is born from individual human beings. We create symbols, and then interpret them. However, the process of interaction between individuals who create each other's symbols and interpret them will produce a certain collectivity which Durkheim refers to as a social fact, or collectivity itself. The process of creating and giving meaning to the symbol, and then passing it on to the next generation, requires memory. The process of remembering so many people on a certain time scale, and then being passed on to the next generation, will form a specific collective memory structure. This collective memory will

${ }^{7}$ https://suaranasional.com/2017/05/20/hampir-terjadi-bentrok-saat-pawai-gawaidayak/ akses 2 Mei 2018.

${ }^{8}$ See also Djajadi (2016). 
remain, and passed on to the next generation, although times are changing, and tradition disappears (Wattimena, 2012: 2). According to Confino (1997: 1389) Memory as a study of collective mentality provides a comprehensive view of culture and society that is often lost in the history of memory.

Each community in the world has a past. In fact, as Robert Bellah claimed, the so-called communities are determined by what happened in their past. $\mathrm{He}$ argued, that a true community is a community of memories, a community based on a past, and never forgetting it. To preserve its past, a community, according to Bellah, needs a story. They create stories that contain meaningful values for the community. Such stories are very important to preserve and develop the collective identity of the community. However, not only are stories told about the good and success of the past, but also stories about painful events, and failures that can be learned. Stories of negative events from the past can actually become the bond of a strong collective identity, and create a deep sense of togetherness. "And if a community is completely honest," as Bellah wrote, "they will remember stories not only of the suffering it receives, but also the suffering it causes --dangerous memories, because it invites the community to transform the ancient evil" ( Wattimena, 2012: 6).

Olick (Widjaja, 2010: 15) mentioned about the three principles for analyzing memory and processing the content in it. First the collective memory is not monolithic. Collective warning is a very complex process, involving many different people, practices, materials, and themes. Secondly, the concept of collective memory will encourage us to see memory as an authentic residue of the past or vice versa as a dynamic construct in the present. The complex recall process is always a fluid negotiation process between today's desires and relics of the past. Third, it must be remembered that memory is a process, and not an object. Collective memory is something we did, not something we had. Therefore a sensitive analysis tool that is sensitive to diversity, contradictions, and dynamics is required. Thus the memory first forms in the present as well as in the past and is something that is not fixed. Memory is something that lives in dynamics at both the individual and collective levels. For the purposes of this paper, the term collective memory refers to the collective memory among the Malays in the form of past stories, beliefs, practices, and which have become traditions such as farming.

\section{BELIEF}

Although belief / Religion -in addition to language and culture-- as a major marker of the Malay and Dayak differences, traces of old beliefs can still be traced in the daily life of the Malay and the Dayaks. This trust trail shows the 
collective memory of the Malays. Some of these will be described below. In the Malay community, especially in the interior, there are people who still perform the ancak ritual. Ancak is woven trays for offerings to supernatural beings (Gimlette, 1971:2). The offerings are usually made up of food ingredients. It is believed that performing the ceremony can affect the luck and misfortune of a person in addition to treating the sick. This ceremony was prevalent among the people of the archipelago in the past. Among the rural communities of West Kalimantan, this ceremony was performed by the Dayaks as well as by Malays.

There is also a tolak bala (prevention of misfortune) ceremony. The ceremony is performed with certain ceremonial devices in the form of food that will be placed on the border of the village. The purpose of this food disposal is to feed the magical powers in order to persuade them not to disturb the peace of the village. Along with the ceremony was reading prayers according to Islamic beliefs (Hermansyah 2002). The Malays continued their ancestral traditions before Islam in the form of feeding the supernatural beings believed to affect their lives along with the recitation of Islamic prayer.

In addition, there are also beliefs related to the livelihood. In lan-clearing for farming, for example, it should start on certain days or based on instructions through dreams or listening to the instructions that come from the sound of birds. Likewise the determination of the day begins to sow the seed and during harvest. In fishermen communities, they also develop certain beliefs for example one should not whistle or say dirty words at the time of looking for fish associated with the catch and the safety of fishermen.

There is also a belief called kempunan sometimes called kepunan or mpunan. Kempunan is a dangerous situation caused by a person's desire to eat and drink that has been declared or an offer to eat or drink that is not met. ${ }^{9}$ This situation causes a person to be threatened or bitten by certain animals such as snakes, centipedes, scorpions or accidents such as falling because of being driven by supernatural beings. Usually a person who does not fulfill the wishes or take offers to eat or drink, he will get misfortune like a wound, falling off or being bitten by a venomous animal which is believed to have occurred due to a kempunan. To avoid the situation, someone must eat or drink, or at least does mlopus. ${ }^{10}$ Evidence that this kempunan being part of the collective memory of the Malay can be traced to the Dayak society. According to Bernstein (1997: 67) kempunan is an integral part of daily culture in the upper Kapuas River, (1959: 553)

9 Compare to the definition of kempunan by Kamus Dewan (2002: 535) and Wilkinson

${ }^{10}$ Touching food and baverages with your finggers and put the left over food and or baverages in them to your mouth (Hermansyah, 2010: 82, 94). 
including in the Dayak Taman community, which became the focus of his study. Apparently such a belief not only belongs to the Kapuas River upstream community, the Kadayan Dayak community in Brunei also has a similar belief (Maxwell 2005).

The belief in the "spirit" of many living and dead objects is another example of the existence of the Dayak and Malay origins. Another example is associated with pantang larang (prohibition). Traditional people of West Kalimantan believe that rivers and lakes should not be poisoned because it will lead to natural events that threaten human safety such as rain accompanied by thunder and lightning. Pantang larang is related to keeping the water ecosystem and the water itself from pollution (Hermansyah, 2016: 351). Respect for the right to living freely is not only given to humans. Some West Kalimantan people believe that animals should not be laughed at or tortured, especially for prospective parents. If breached, it will result in the same fate that befalls the baby to be born. This belief is called kenawa'. Besides kenawa' Malays also believe that, hurting animals and laughing at them can lead to lobur. Lobur is the occurrence of storm accompanied by lightning and thunder that turns a person who hurts animals and laughs at them into a rock (Hermansyah, 2010: 58). The fact that this belief is a form of Malay collective memory of the ancestral heritage prior to Islam is seen in similar beliefs among the Dayaks. Beliefs about this lobur for example is similar to the Dayak Kayan belief called Adat Dipuy. In this custom the Dayak Kayan people believe that treating animals, especially monkeys, frogs, pigs and dogs arbitrarily and laughing at them can cause strong winds and thunder. The difference is, in the strong wind and thunder does not turn a person into a rock (Rousseau 1998: 105).

\section{HERITAGE}

In the collective memory of the Malays, they have long claimed to have a kinship with the Dayaks. To prove it, they usually have a tembawang inherited from their ancestors. The owner of the tembawang consists of Dayaks and Malays. Tembawang is an old farm planted with various fruit plants such as durian, mangosteen, rambutan, mango, and so forth. In the fruitful season, the Dayaks will tell their Malay relatives to take some fruit or sometimes send the fruits to them. Likewise, if the Dayaks go to the Malay village, they will be accepted and treated as relatives. In the past, many Dayak people sent their children to school and entrusting them to the Malays. The Malay host is even responsible for providing food, drink, and tuition for the Dayak children.

In addition to tembawang, the Malay (and possibly Dayak) inherited the same story as the Dayak. According to Wattimena (2012: 4) stories about the past 
usually settles into a kind of folklore that contains moral values going to the next generation. The story becomes meaningful, because it contains the past wisdoms that need to be inherited and interpreted by the next generation. In the stories of the past, and the moral and wisdom values contained therein, collective memory plays an important role in giving meaning and context. Folklore becomes a tool for collective memory to give a social identity to a particular community. In Kapuas Hulu, there is a famous Demang Nutup story as their ancestors. Here is a version of the story (Hermansyah, 2010: 211-212):

"Grandfather Demang Nutup came from the people of heaven. His wife was Sunta Bonang. They had sixteen children who then became the Chinese, Kantu, Iban, Taman, Tebidah, Punan and Bugis. The one who became Malay was in our place [Embau].

Grandfather Demang Nutup always went to the top of Beluwan Hill --which was then still connected with the Ampan Hill-- to see the tree of a thousand branches growing on top of the hill. The tree of a thousand branches was wrapped in the roots that end up in the sky. The roots were used by the Grandfather Demat Nutup to come down from heaven to earth. Apparently the roots were also used by the Siang Burung ghost to descend to earth to kill humans. One day Grandfather Demang Nutup went to see a thousand branchwood trees to watch if the Daylight ghost descended to earth. Because of concern for the safety of his children, the roots were cut off by Grandfather Demang Nutup. From then on, no man could climb to the land of heaven anymore.

After cutting the roots, he felt hot. To cool his body, Grandfather Demang Nutup bathed in the Klawan Bluwan pool. During bath, Grandfather Demang Nutup got a Tambun fish which is big as an adult gurami fish. When he finished bathing, he went back to the village with the Tambun fish wrapped with a bathing cloth. Arriving at home, the fish was immediately given to his wife for cooking. When his wife opened the wrap, all she found were the bones of fish because the meat had been eaten by the tuma. Even so, the fish bone was still cooked with cucumber leaves.

After the fish one and cucumber leaves was ready, his son immediately ate it. During the meal, his son had a bone stuck in his throat. Grandfather Demang Nutup was furious. He immediately went to the foot of the hill and kicked the hill. "Seves you right! the fish that I got from your pond caused my son to get bone stuck in his throat," he said. The Ampan Hill at the top of Beluwan Hill was finally separated. Ampan Hill then floated in the air. Seeing the Ampan hills floating in the air, other hills asked him: 
"Ampan Hill, where are you going?"

"I want to cover the Embau River," said Ampan hill.

Hearing the conversation, lokan ${ }^{11}$ Maram replied, "Wait, let's cover the River together. Please drop by here first. I still have unfinished work." When Ampan Hill stopped there, half the hill plunged into the ground and could not move anymore. That's where the Ampan Hill stopped so it's now downstream of the Nanga Pedian village."

The story above is actually a legend about the origin of a hill. But in that story, the central figure believed by them as their ancestor was also the ancestor of the people of other tribes. In addition to the story, the Malays and the Dayaks inherited a number of similar folklore. The story of Pak Saloi --or in some places called Pang Aloi-- is an ancestor's folklore about the humorous figures shared by the Malays and the Dayaks.

Furthermore there is a legacy of the same farming system among the two ethnic groups. Overall, the cultivation system among the Malay cultivators / activities which is the main activity of rural communities in the interior is mostly the same as that of the Dayak. The time-consuming farming activities of the Malays were reported Hermansyah (2010: 25-27) as follows:

The first activity is Ngabas Tanah. This is an activity to check and review some places planned to be used as a field or huma. At the time of examining this land sometimes they also got a burung-biu (signs) $)^{12}$ whether the land should be used as a huma that year or look elsewhere. The sign can be a dream, a feeling or can also be a state that can be used as a guide like a sick family member. If during the search for a suitable field and no unfavorable burung biu is found, the next stage is Nobas. This activity takes place around May or June.

Nobas, is the activity of cutting the grass on the sidelines of a large tree located on the land to be used as a huma. For those who will farm in mpalai ${ }^{13}$ which is rather new, usually this activity is take place later than those who will take on the old mpalai or open a new land. This

${ }^{11}$ Lokan means swamp

${ }^{12}$ Similar belief to Dayak people. Within the Dayak people, a bird has an important role for giving hints for human life as reported by Van Hulten (1992: 218-219). In addition, the Dayak people also believe that forest is also inhibited by supernatural beings that must be respected so that when starting the work of new land for a farm in the forest, for example, they need to ask for a permission. This kind of belief within Dayak people is also repoted by Radam (2001: 328-337) and Fatmawati (2011: 133).

${ }^{13} \mathrm{~A}$ piece of land that has ever been used as a farm in the past years. Mpalai means smal bushes and woods. The level of work to spend to the bushes and woods depends on the length of the mpalai being left for unsed. 
farming system is commonly known as shifting cultivation. Although the farming land shifts, they have traditional wisdom to preserve the forest. Instead of believing in certain forces that govern nature, they are also accustomed to taking advantage of the mpalai after being left for several years. So they do not clear a new land every year. For land that is not productive because of reduced fertility if used as a field then the land will be used plantation, especially rubber. In contrast, old rubber gardens that are less productive are cut down and used as fields. This shifting cultivation system proves to be not only an appropriate answer to the "struggle" for sustaining life on infertile soil, it is also a major alternative and appropriate mechanism, at least in transition to a fully settled agricultural system. In the last ten years it has been very rare for Malays to clear new forests for agricultural land. The following illustrates the cycle of land use for Malay people:

Chart of

Land Cycle for Farming

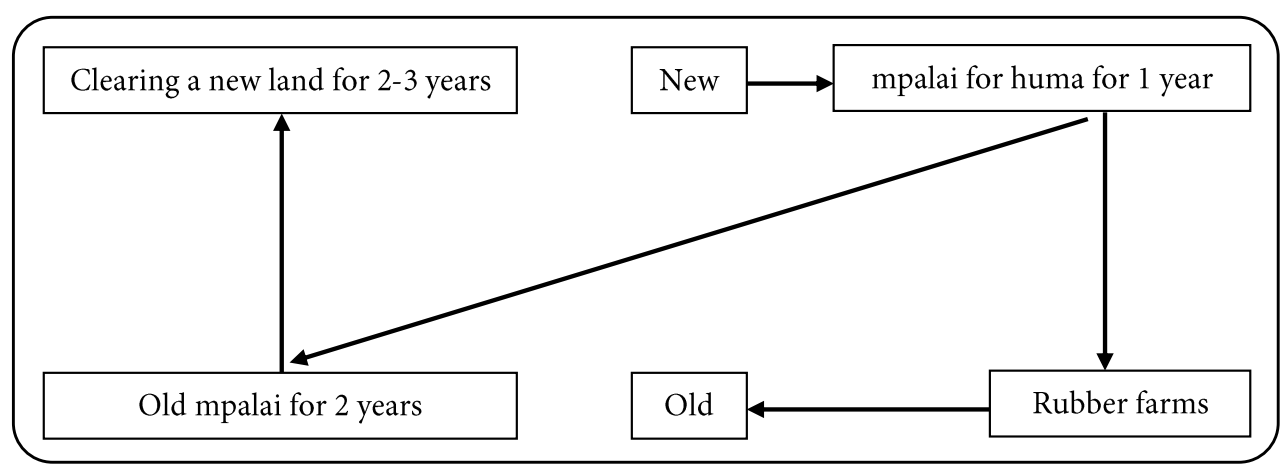

After finishing nobas, the next activity is nobang, which is cutting down wooden trees. This activity is only done on a new land or an old mpalai. After being cleared, the land is left for about a month waiting to dry before the next activity.

$N u n u$, i.e. burning the uma, is done after the trees and grass have been cut down and let to dry. If the land is adjacent to the forest or farm, then before the burning, the land should have a doda ${ }^{14}$ of 3-5 meters wide. Before burning the land, the owner of the field will tell the owners of the surrounding land to keep the fire from spreading.

After completion the nunu, the next activity is ngokas, that is activity to clean

${ }^{14}$ Means clearing dried grass/bushes and woods on the land bordered with forest and farm so that help protect the fire to escalate to unwanted area when the burning work takes place. 
the remains of burning. The length of time for this ngokas depends on the first burning result. If the season is less hot, usually it is not good and the time to do ngokas will be longer and vice versa. Unburned woods in the nunu period will be cut and stacked for re-burning.

When finished with ngokas, the next activity is nugal, that is planting rice with tugal. Between the rice plants, people usually grow vegetables, such as mustard greens, jawa', pare, spinach, corn, chives, chili, eggplant, cucumber, and pumpkin.

The next two months came the mabau period, which is clearing the grass that grow on the sides of the rice and vegetables. At this time some types of vegetables can be picked, such as spinach, chives and young corn. Approximately a month after the mabau, for those who plant the pulut (glutinous rice), came the time for ngompin. Ngompin is the activity to make ompin (emping) from sticky rice. A month after the ompin season came the harvesting season (ngotam). Rice stems are harvested one by one, collected and then threshed to remove the grain. After that the grain is dried in the sun, it is burned with a bushel. After that, some of the rice is separated for seeds for the next planting season, some are ground to be used as rice and some are stored inside $k u j u k^{15}$, if they need it, they will take the rice from the kujuk to be ground or sold.

The whole series of farming activities are usually done by way of bebung, which is doing the huma en mass with a roll from one huma to another. The most frequent activities by way of bebung in berhuma are nobas, nugal, and ngotam. In addition, there is also magic called ilmu among the Malays that is inherited from their ancestors prior to Islam. Hermansyah (2010) reported that a number of $i l m u$ shows the heritage of the ancestors. ${ }^{16}$ In addition to the Islamic element in $i l m u$, there are also local elements that show the heritage of tradition, among others, similar or even the same beliefs with those among the Dayaks. Here are some examples;

Semati anak mati anak

Mati ditingang tanah tamak

Totak buluh panyang panak

Pakai nyuman porut simati anak

\footnotetext{
${ }^{15}$ A peace of work in the form of a box made of wood to store padi (rice). Kujuk is normally in $1.5 \times 5$ meters and placed in a room between kitchen and main body of the house.

${ }^{16}$ It is also the same as the people of Dayak Lawangan who have converted to Islam as reported by Mallinckrodt (1974)
} 


\author{
(Dead child [ghost] \\ Died of landslide \\ Cut baboo long and short \\ To stab the stomach of dead child [ghost])
}

(Hermansyah, 2010: 145)

This mantra indicates a heritage of the ancestral belief of the Malay prior to Islam that the bleeding that occurs at the time a mother gives birth is caused by the ghost of a dead child. To treat it, then the mantra is recited. This belief is clearly a belief of an unknown tradition in Islam. Another example of another mantra used to treat children who cry a lot as follows:

To bathe a crying child

Kuak kabak cencang dade dulang

Daging dan tulang tekerambak

Buang luge dalam tulang

Nek uyuk merang kajang

Teparang kamunie

Antu buyuk antu bajang

Sahabat manusia

(Lala, 2007: 93)

Tawar sawan Serabi

Kaciku secangak secingar

Ngacip kaki babi

Ambik kencor dengan jeringau

Aku menawar nenek rerabi

(Lala, 2007: 94)

In contrast, the Dayaks were influenced by the Malays in their spells. Although they do not convert to Islam, they have been influenced by the Malays, more precisely by Islam in their mantra while maintaining the local elements. Here are some examples of mantras that show the influence of Islam practiced by the Dayak Kanayatn in Landak area.

Tawar api/air panas (Burn treatment)

Bismillahirahmanirrahim

Turun jaki naik jai

Makan rokok sirih sakabat

Bukan aku nawari' kena' api/air

Aku nawari hujan yang lebat

(Apan in Hermansyah, 2013: 349) 
Tawar mata (Eye treatment)

Bismilah ya rahman ya rahim

Ambun ijau ambun kuning

Ambun manikam raja manawar

Aku nuruntan tawaran saribu

Anak ikan putih dari lautan

Panas sajuk barat ringan

Tajam tumpul bisa tawar

Sah tawar

(Maria Ate, in Hermansyah, 2013: 349)

Tawar Kempunan (Kempunan treatment)

Bismillah ya rahman ya rahim

Pariu' si parunggu

Barisi' ruman padi

Turun dato' petara guru

Nawari' kempunan ku tadi'

Jilat makatn

(Alau Akbar in Hermansyah 2013: 349)

This situation also occurs among the Dayak Tunjung and Benuaq people who are Christians in East Kalimantan practicing mantras with those influenced by Islamic beliefs such as in the following ilmu asar text:

bismillah neraman arahim

sang putih raja manak

asal orang putih tak belawan

(Hopes 1997: 112) in the name of Allah, The Merciful and Compassionate

White Lord, King [of] Children

because of a man's white origin, he shall not resist

From some of the above examples it is evident that the Islamic element in the Dayak mantra is the mention of bismillahirrahmanirrahim which means 'in the name of Allah the Most Beneficent, the Most Merciful'. This sentence is the first verse in the first Surah of the Quran that is al-Fatihah. It has become common knowledge among Muslims to make this sentence a greeting to start a good work to be of value before God. 


\section{SOCIAL RELATIONS}

In order to maintain social relations and respect for their Dayak relatives, the Malays chose to call themselves orang darat (land people). Even this is very common when they are talking about a Dayak as a third person. The term darat (land) refers to a marker of direction among the people of Kalimantan other than the laut (sea), hulu (upstream), and hilir (downstream). ${ }^{17}$ Laut refers to the river, and land is in the opposite direction. "Hulu" refers to a water source or upstream of the river and "hilir" points toward the mouth of the river. The direction of the wind is unknown in the traditional direction system of the people in Kalimantan. Even if using the sun as a sign, they just call the direction of the sun lives and the sun dies to refer east and west. The north and south directions are completely unknown. They do not want to call their relatives Dayak. For in the beginning the name of Dayak was an insulting term for non-Muslim indigenous peoples in the interior of Kalimantan (Sellato, 1989). In the perspective of scholars of colonial anthropology at that time, the term Dayak was always depicted in the Western world as an underdeveloped group of humans who like to wage war between tribes and move from one region to another (Isman 2016: 364).

While among the Dayaks in Melawi and Sintang, they call their Muslim brothers as "senganan" (Fatmawati, 2011: 167) which means the right side in the sense that they still are close relatives. In fact, these Muslim 'senganan' still continue their Dayak customs that are modified and adapted to Islamic teachings. By doing so, the Muslim 'senganans' realize that they are actually Dayaks or at least have the same ancestors as the Dayaks. In contrast, the Dayaks recall that they also have brothers who subsequently turned their ethnicity into a 'senganan'.

In the context of relations between ethnic groups there are good habits and continue to be maintained until now, especially in the interior. In certain Dayak villages, there is a special custom of serving Muslim guests. In order to respect the Muslim guests they prepare special cutlery and cookware that they do not use. ${ }^{18}$ In addition, sometimes guests are also served with food that has not been cooked. That way, Muslim guests can process their own food without feeling anxiety. Therefore, Muslims who come to a Dayak village will feel at

${ }^{17}$ Maunati (2006: 178-179) mentions that the Dayak use direction terms as hulu (ulu) or upper area and hilir (ilir) or lower area since most Dayak settlements are located in the river sides so that they understand the direction as associated to river flow. In addition, the ulu-ilir terminology also has important simbolic meanings for the Dayak. Ulu also means life and Ilir means death. Ilir is also associated to city or more deceloped area or urban. Maunati doest over an explanation on the concept of darat and laut.

${ }^{18}$ As commonly understood, Islam has a specific concept of law with reagrds to food and baverage, some of them are allowed to be consumed by Muslims and some other not. 
home. $^{19}$

In regulating social relations, the traditional communities of West Kalimantan have customary law. Customary law is still applied by some Malay communities, very closely related to the Dayak customary law. For example, in rural communities of West Kalimantan, particularly in Hulu Gurung, Kapuas Hulu District, they recognize the term of the customary law namely pamar darah. The pamar darah penalties apply to a person or group of people who create a rowdy atmosphere and shock people; for example someone walking in the middle of the village carrying a machete or other weapon while shouting. The perpetrator will be subject to certain customary sanctions. These customary laws have prevented fights or vigilante actions. Among the Dayak Landak people, they have a similar custom called Pamabakng custom which is made to resist various acts of violence (Kristianus, 2009: 121).

\section{CHALLENGES}

The Malay collective memory lives in a vibrant sphere of life. Therefore, changes due to external influences or the drive from within is inevitable. There are many things that affect the collective memory of a community. At least there are four things that are very influential on the collective memory of Malays in West Kalimantan namely, social segregation, modernization, politics, and religion. For a long time, local Muslims who converted to Islam -and gained a new identity as Malay--made new settlements separate from the original. Thus geographically the Dayaks and the Malays have long been separated from each other. Almost no more heterogeneous villages exist --in terms of a relatively balanced number of Dayaks and Malays-- in West Kalimantan. Although there are some, but one can hardly find villages inhabited together by the Malays and the Dayaks. There are indeed Dayak villages in which some Malay people live or vice versa. The social separation of the Dayaks and the Malays has begun during the Dutch colonial era, as mentioned in the previous section, for the purposes of running public administration and daily social communication of the general public, and to support the spread of Christianity to indigenous people labeled as Dayak people.

It must also be stated that there are other situations among Dayaks who convert to Islam in Kalimantan. For example, Dayak Bakumpai people in Central Kalimantan and South Kalimantan still maintain their Dayak identity even though they are Moslems (Nasrullah, 2014) as the case of the Benuaq people in East Kalimantan (Yusriadi et al., 2012: 55). Likewise in Brunei, in the country's constitution it is stated that the Malays consisted of the original

\footnotetext{
${ }^{19}$ Compare to Fatmawati (2011: 145-146)
} 
Brunei friars of Belait, Bisaya, Brunei, Dusun, Kedayan, Murut and Tutong, regardless of their religion and belief (Hermansyah, 2015: 2 ). Based on such circumstances, especially in East Kalimantan, Maunati (2006: 85) asserted that the boundaries between Dayak and Malay are not very strict, and the limitation of one's Dayak identity is always changing. Thus according Maunati the use of ethnic terms in the context of religious differences is misleading.

Modernity that brings nature to rational thinking has transformed people who believe in supernatural and mythology to something logical and empirical. The process of modernization is channeled through education and cultural literacy. Education and cultural literacy has brought a new cultural element among people of Kalimantan. The stories in the textbooks come mostly from other cultures. While the oral tradition speakers who remind their past are diminishing. In everyday life the use of modern tools and technology among the Malays is increasing. This has improved efficiency and reduced their dependence on nature. By itself, some of the collective memory that bridges them in touch with nature with its various beliefs is also eroded.

Another factor that also greatly affects the collective memory of the Malays is politics. Strong ethnic politics has influenced the Malay ways of thinking and acting. When the election of competing regional head candidates is Malay and their political opponents are Dayaks then identity politics is strengthened. The strengthening of ethnic identity --in this case Malay and Dayak-- is needed to attract the sympathy of each group. The rivalry of political elites involving ethnic identity has had an effect on the lack of harmonious political relations among some Dayak elites and the Malay in politics (Isman 2016: 362). In this context the collective memory that reminds them of their brotherhood may be forgotten, as opposed to the political interests of the elites. The collective memory here is seen as the subjective experience of a social group that can basically support power relations (Confino, 1997: 1393). This situation will get worse if there is dominance control of government bureaucracy --ignoring the competence and professionalism-- when members of one ethnic group wins the election of the regional head of government. This political competition has also affected their collective memory. Because of the competition, some people find it unnecessary to maintain a collective memory that reminds the similarity of their origin. Differences of interest can make memory a captive of reductionism and political functionalism (Confino, 1997: 1395).

Religion is also a factor that greatly affects the collective memory of the Malays. The presence of Islam has brought many changes to West Kalimantan Malay people who choose to embrace this religion, including in terms of culture. Although the Malays do not entirely abandon local traditions, the 
Malay reasoning slowly supersedes the old ways that al-Attas (1969: 4-7) aligned it with the transition of Western worldviews previously influenced by the Greek mythology to the world of reasoning and enlightenment. As Islam gets stronger, some of the traditional beliefs and practices are abandoned. The elements of abandoned local culture are especially contrary to the teachings of Islam. In this perspective, practicing local culture can disrupt their Islamic "purity". Moreover, lately there is the behavior of religious fanaticism of some Muslims under the banner of Islamic fundamentalism which is trying to suppress everything they call un-Islamic. With this kind of religious approach, the Malay collective memory that reminds them of their origins and their brotherhood with the Dayaks is also affected and even gradually eliminated. Nevertheless, the Islamic teachings on the equality of human origins and human degrees before God can be the bond for these two ethnic groups (Surah Hujurat: 13).

Nevertheless, the similarity of the fate of the Dayaks and the Malays is a factor that can strengthen their collective memory. The removal of local people (read Dayak and Malays) from land ownership in the name of economic growth, development and modernization on the worst side has slowly made them lose their livelihood. At the same time the power of capitalism has eliminated their cultural roots which are very close to nature. If collective memory of the same origins is preserved by them, it is not unlikely that it will be a trigger to rise up against the forces that eradicate their history.

\section{CONCLUSION}

The relationship between the Dayaks and the Malays in West Kalimantan is relatively harmonious. This good relationship has a strong historical roots in the people of West Kalimantan. As many researchers have noted, the vast majority of people who are now called Malay in West Kalimantan are actually local people who have been Muslim since hundreds of years ago. The awareness of being brothers to a local community now called "Dayak" is in fact an entirely historical consciousness. Therefore, the consciousness of a more genuine relationship because they come from a common ancestor is commonplace. In fact, recently the awareness has been disrupted by the interests of a handful of elites who take advantage of ethnic and religious issues for specific purposes.

The relationship is recorded in the Malay collective memory --and possibly also among the Dayaks. Memory is formed in the present as well as in the past and is something that is not fixed. Memory is something that lives in dynamics at both the individual and collective levels. Memory is maintained or removed depending on the needs. The collective memory is maintained or eliminated 
by various factors. Among the important factors that may accelerate the loss of collective memory include: social segregation, modernization, politics, and religion.

\section{BIBLIOGRAPHY}

Alqadrie, S. I. (2007). Pilkada KalBar, Pemekaran Wiayah dan Hipotesis 2020-an, in Harian Umum Pontianak Post, 23 Mei: 19.

Bernstein, J. H. (1997). Spirit captured in stone: shamanism and traditional medicine among the Taman of Borneo. Colorado: Lynne Rienner Publisher.

Chalmers, I. (2007). The Islamization of Southern Kalimantan: Sufi Spiritualism, Ethnic Identity, Political Activism. Studia Islamika, 14 (3): 367 417. DOI: 10.15408sdi.v14i3.542.

Confino, A. (1997). "Collective memory and Cultural History: Problems of Method." The American Historical Review, 102 (5): 1386-1403.

Djajadi, I. (2016). Kekerasan Etnik dan Perdamaian Etnik: Menelaah Penyelesaian Tindak Pidana Lintas-Etnik dalam 4 Tahun Terakhir di Kalimantan Barat. Dlm. http://iqbal-djajadi.blogspot.co.id/2016/12/kekerasan-etnik-dan-perdamaian-etnik.html. Akses 2 Mei 2018.

Enthoven, J.J.K. (2013). Sejarah dan Geografi Daerah Sungai Kapuas Kalimantan Barat. Terj. P. Yeri. Pontianak: Institut Dayakologi.

Erll, A. \& Nünning, A. (2008). Cultural Memory Studies: an International and Interdisciplinary Handbook, Berlin: Welter de Gruyter GmbH \& Co.

Fatmawati. (2011). Harmonisasi antar Etnik di Kalimantan Barat: Studi Etnografi Melayu dan Dayak. Pontianak: STAIN Pontianak Press.

Fentress, J. and Wickham, C. (1992). Social Memory. Oxford: Basil Blackwell.

Gimlette, J.D. (1971). A dictionary of Malayan medicine. Kuala Lumpur: Oxford University Press.

Heidhues, M. S. (2008). Penambang Emas, Petani, dan Pedagang di "Distrik Tionghoa" Kalimantan Barat. Terj. Asep Salmin, dkk. Jakarta: Yayasan Nabil.

Hermansyah. (2002). Magi Ulu Kapuas: Kajian atas Ilmu masyarakat Melayu Embau. Tesis Magister Program Pascasarjana IAIN Walisongo Sema- 
rang.

(2010). Ilmu Gaib di Kalimantan Barat. Jakarta: Kepustakaan Populer Gramedia, EFEO, STAIN Pontinak, dan KITLV.

. (2013). "Islam dan Toleransi Beragama dalam Masyarakat Muslim Kanayatn Dayak di Kalimantan Barat." Islamica: Jurnal Studi Keislaman. 7 (2): 340-359. DOI: https://doi.org/10.15642/islamica.2013.7.2.340-359

. (2015). Islam dan Melayu di Borneo: IAIN Pontianak Press.

-------. (2016). Modal Damai dari Kearifan Lokal Masyarakat Kalimantan Barat. Dlm. Zainuddin Isman, dkk (eds.) Kebudayaan: Interaksi Sosial, Konflik \& Perdamaian. Pontianak: Alqadrie Center Press. pp. 349359.

.. (2018). "Khalfīyat wa ta冈addīyāt al-aqalīyah al-muslimah al-囚īnīyah fi Pontianak." Studia Islamika 25 (1): 135-176. DOI: 10.15408/sdi. $\underline{\mathrm{v} 25 \mathrm{i} 1.6034}$

Hopes, M. (1997). ILMU Magic and divination amongst the Benuaq and Tunjung Dayak. Jakarta: Puspa SWARA

Isman, Z. (2016). Pembentukan Identitas Dayak dan Perubahan Menjadi Melayu di Kalimantan Barat. Dlm. Zainuddin Isman, dkk (eds.) Kebudayaan: Interaksi Sosial, Konflik \& Perdamaian. Pontianak: Alqadrie Center Press. pp. 360-378.

King, V. T. (1993). The peoples of Borneo. Oxford: Blackwell.

Kristianus. (2009). Kisah Penting dari Kampung: Orang Dayak \& Madura di Sebangki. Pontianak: Yayasan Pangingu Banua, Cordaid, dan STAIN Pontianak Press.

Lala, A. (2007). Magic Tanah Kayong: Studi atas Ilmu Pengobatan Masyarakat Dusun Pedalaman Kendawangan Ketapang. Skripsi STAIN Pontianak.

Lipsitz, G. (1990). Time Passages: Collective Memory and American Popular Culture. Minnesota: University of Minnesota Press.

-------, (1990). “Front Matter." In Time Passages: Collective Memory and American Popular Culture, I-Iv. University of Minnesota Press http:// www.jstor.org/stable/10.5749/j.cttttz1b.1.

Maunati, Y. (2006). Identitas Dayak: Komodifikasi dan Politik Kebudayaan. Yogyakarta: LkiS.

Maxwell, A. R. (2005). The cultural construction of danger in Brunei. Kertas 
kerja pada persidangan antarabangsa The languages and literatures of western Borneo: 144 years research. Bangi. 31 Januari-2 Februari.

Mallinckrodt, J. (1974). Gerakan Nyuli di Kalangan Suku Dayak Lawangan. Terjemahan Winarsih Arifin. Jakarta: Bhratara.

Nasrullah. (2014). “The IslamicTradition of Bakumpai Dayak People.” Al-Albab: Borneo Journal of Religious Studies (BJRS). 3 (1): 39-53.

Olick, J. K. and Robbins, J. (1998). Social Memory Studies: From "Collective Memory" to the Historical Sociology of Mnemonic Practices. Annual Review of Sociology. 24 (1): 105-140. https://doi.org/10.1146/annurev. soc.24.1.105

Radam, N. H. (2001). Religi Orang Bukit. Yogyakarta: Yayasan Semesta.

Rousseau, J. (1998). Kayan religion: ritual life and religious reform in Central Borneo. Leiden: KITLV Press.

Sellato, B. (1989). Naga dan Burung Enggang. Hornbill and Dragon. Jakarta: ELF Aquitaine Indonesie.

. (2002). Innermost Borneo: Studies in Dayak culture. Paris: Seven Orients \& Singapore University Press.

Van Hulten, H. J. (1992). Hidupku di antara Suku Daya. Jakarta: Grasindo.

Veth, P.J. (1854). Borneo's Wester Afdeeling. Geografisch, statistisch, historisch. Zaltbommel: Joh. Noman en Zoon.

Wattimena, R. A. A. (2012). Teori Ingatan Kolektif. https://rumahfilsafat. com/2012/07/10/teori-ingatan-kolektif/ akses 25 April 2017.

Widjaja, E. (2010). Memori Kolektif Kota Jakarta dalam Restoran Cina. Tesis pada Fakultas Ilmu Pengetahuan Budaya Pogram Pascasarjana Universitas Indonesia.

Yusriadi, (at.al). (2012). Pengetahuan Tradisional Masyarakat Dayak: Studi atas Masyarakat Benuaq di Tanjung Isuy Kalimantan Timur. Pontianak: STAIN Pontianak Press dan BPNB Pontianak.

http://www.tribunnews.com/regional/2016/11/05/jelang-tengah-malam-kelompok-massa-di-pontianak-berjalan-sambil-bersholawat. Akses 2 Mei 2018. 